\title{
Pyrolysis of Coconut Cloth in a Microwave Reactor: Effect of Pyrolysis Parameters on Product Yield and Characterization of Liquid Product and Biochar
}

\author{
Qiqi Dai, Jin Li,* Yang Cao, Xiaocui Wei, Hongbiao Tang, and Jingjing Sun \\ Pyrolysis of coconut cloth was investigated with the influence of pyrolysis \\ process parameters on the maximum products yield and their chemical \\ compositions. With the microwave reactor, the process parameters were \\ as follows: temperature $\left(450^{\circ} \mathrm{C}\right.$ to $\left.650^{\circ} \mathrm{C}\right)$, heating rate $\left(10^{\circ} \mathrm{C} / \mathrm{min}\right.$ to 30 \\ ${ }^{\circ} \mathrm{C} / \mathrm{min}$ ), and nitrogen flow rate $\left(80^{\circ} \mathrm{C} / \mathrm{min}\right.$ to $\left.120 \mathrm{~cm}^{3} / \mathrm{min}\right)$. The highest \\ liquid yield of $38.3 \%$ was observed at $550{ }^{\circ} \mathrm{C}$ for the heating rate of 20 \\ ${ }^{\circ} \mathrm{C} / \mathrm{min}$. The characteristics of bio-oil and biochar were analyzed using \\ chromatographic and spectroscopic techniques, such as nuclear magnetic \\ resonance spectroscopy (HNMR), Fourier transformed infrared \\ spectroscopy (FTIR), gas chromatography-mass spectroscopy (GC-MS), \\ scanning electron microscopy-energy dispersive X-Ray (SEM-EDX), X- \\ ray powder diffraction (XRD), and elemental analysis. The bio-oil \\ contained a higher amount of phenolic compounds at $79.6 \%$. The obtained \\ biochar had a calorific value of $27.8 \mathrm{MJ} / \mathrm{kg}$, which made it a promising \\ candidate for solid fuel.
}

Keywords: Pyrolysis; Coconut cloth; Bio-oil; Biochar; Characterization

Contact information: College of Chemical Engineering and Technology, State Key Laboratory of Marine Resource Utilization in South China Sea, Hainan University, Haikou 570228, China;

*Corresponding author: 316800681@qq.com

\section{INTRODUCTION}

Currently, many fossil fuel energy sources have been developed and utilized, such as oil, natural gas, and coal. Although they can promote rapid economic development, they also bring ecological problems, such as resource depletion and environmental pollution. These problems create the need to find renewable fuels. In this respect, biomass is a renewable energy source that is rich, with low sulfur and nitrogen content and low ash content (Jahirul et al. 2012). Because biomass is composed of abundant carbon, there are many applications in energy, such as heating, power supply, and transportation fuels (Riva et al. 2019). In these applications, biomass requires a multi-step conversion of raw materials, and thermochemical conversion is an effective way. In thermochemical processes, pyrolysis is receiving more attention than other processes because its conditions can be optimized to produce high energy density pyrolysis oils as well as derived biochars and gases (Demiral and Şensöz 2006). Pyrolysis is generally defined as the conversion of biomass into complex liquid fuels, char, and gases through heating, usually in the absence of oxygen (Garcia-Perez et al. 2007). Biomass pyrolysis methods include rapid cracking, direct liquefaction (Feng et al. 2016), vacuum pyrolysis (Cai et al. 2016), and microwave pyrolysis (Yin 2012). Among them, microwave pyrolysis is a better heating method, and the heat conduction method is volume heating, which is superior to the traditional electric 
heating process. Compared with the traditional heating method, microwave heating is fast and has high efficiency, uniformity, easy control, and selective heating, thus improving the yield of bio-oil (Mamaeva et al. 2016). The thermal conductivity of the raw material is poor, and the microwave heating method uses a large amount of heating from the inside to the outside, which can achieve the purpose of deep heating so that the heating process of the pyrolysis process is faster and more uniform (Zhang et al. 2017). Therefore, microwave pyrolysis can be regarded as a better heating method.

Various biomass materials that can be used for pyrolysis include wood, energy plants, forest residues, aquatic plants, and industrial waste, and these are all considered renewable energy sources (Park et al. 2014). Coconut cloth is a high-quality agricultural product in biomass. Coconut cloth belongs to tropical biomass, and the main production in Hainan is rich in coconut resources, with an annual global output of 62.5 million tons. According to the literature survey, only $50 \%$ of Hainan's coconut cloth is used, and most of that material is abandoned, resulting in a great waste of resources (Raj and Joy 2015). The study of coconut cloth is rare. Coconut is a tropical biomass agricultural waste in Hainan. It contains higher lignin and obtains higher phenolic liquid fuels. Phenol and phenolic derivatives have important applications in the pharmaceutical, synthetic fiber and perfume industries. This study provides a theoretical basis for the pyrolysis conditions of microwave pyrolysis coconut cloth and lays the foundation for the comprehensive utilization of tropical biomass coconut cloth wastes in Hainan. For the efficient use of biomass resources, a detailed study of other parts of the coconut, such as coconut cloth, was carried out. The coconut cloth is a thick layer of brown fiber, accounting for $33 \%$ to $35 \%$ of the quality of coconut fruit, and is mainly composed of cellulose, lignin, and hemicellulose. The cellulose composition is a renewable resource with an extremely high yield.

Therefore, coconut cloth was selected as feedstock for bio-oil and biochar production. The aims of this study are to determine the influences of pyrolysis parameters on product yields and characterize the bio-oil product using different spectroscopic and chromatographic methods to evaluate whether it can be used instead of fossil fuels.

\section{EXPERIMENTAL}

\section{Materials and Methods}

Feedstock preparation and product analysis

The biomass sample (coconut cloth) was collected from Hainan (China). Prior to its use, coconut cloth was dried and ground into smaller granules using a pulverizer. Approximate compositions of coconut cloth and biochars were determined according to ASTMD3172-07 (2007), on a dry basis. The percentage of fixed carbon content was calculated by means of the difference. Ultimate analysis was performed to determine the elemental compositions of coconut cloth, and the liquid products and biochars were analyzed using a CHONS elemental analyzer (Flash 2000; Thermo Fisher Scientific, Waltham, MA, USA). 


\section{Characterization of liquid product}

Physical properties of the liquid products were tested, including density, viscosity, water content, etc., according to ASTM standard test methods. The kinematic viscosity of the bio-oil at $40{ }^{\circ} \mathrm{C}$ was measured according to ASTM D4486-10 (2010), and water content of the bio-oil was determined using a Karl-Fischer titrator (KF-MA-1; Ben Ang Instrument Co., Ltd., Shanghai, China).

Fourier transform infrared spectroscopy (FTIR) (TENSOR27; Bruker Corporation, Billerica, MA, USA) was used to determine the chemical groups (bonds) present in the bio-oil. The $\mathrm{pH}$ of the bio-oil was analyzed using a PHS-3E $\mathrm{pH}$ meter (Yantai Stark Instrument Co., Ltd., Shanghai, China) and measured at room temperature. The nuclear magnetic resonance spectroscopy $\left({ }^{1} \mathrm{HNMR}\right)$ analysis of the bio-oil was performed using a NMR spectrometer (Bruker-400M; Bruker Corporation, Billerica, MA, USA). The bio-oil samples were analyzed by gas chromatography-mass spectrometry (GC-MS) (HP 6890/5973 MSD; Agilent Technologies, Inc., Santa Clara, CA, USA), which was equipped with a TCD detector and HP-5ms column $(30 \mathrm{~m} \times 250 \mu \mathrm{m} \times 0.25 \mu \mathrm{m})$.

\section{Characterization of biochar}

The physical form of biochar was studied by scanning electron microscopy (SEM) (Quanta FEG250; Jeol Corporation, Jeol, Japan). The surface area of the biochar was estimated by nitrogen adsorption at $77 \mathrm{~K}$ using an automatic adsorption instrument (ASAP2460; Micromeritics Instrument Corporation, Norcross, GA, USA). To understand the characteristics of the biochar powder, X-ray diffraction (XRD) was performed using AXIS SUPRA X-ray powder diffraction (Kratos Analytical, Ltd., Manchester, England). Functional groups were analyzed in the infrared region of $370 \mathrm{~cm}^{-1}$ to $7500 \mathrm{~cm}^{-1}$. Morphology and elemental characteristics were determined by using an energy dispersive X-ray (EDX) spectrometer (Bruker d8 Advance; Bruker Corporation, Bremen, Germany).

\section{Calorific value}

Ultimate analysis was used to calculate the high heating value (HHV). Equation 1 was used to calculate the HHV because the oxygen content in the precursors and the products was greater than $15 \%$ (Rout et al. 2016):

$$
\mathrm{HHV}(\mathrm{MJ} / \mathrm{kg})=0.336 \mathrm{C}+1.418 \mathrm{H}-(0.153-0.000720 \mathrm{O}) \mathrm{O}+0.0941 \mathrm{~S}
$$

\section{Experimental apparatus}

The pyrolysis test was conducted in a laboratory-scale microwave pyrolysis reactor, and pyrolysis of the biomass material (coconut cloth) was performed in a laboratory-scale microwave oven tube (CY-PY1100C-M; Hunan Changyi Microwave Technology Co., Ltd., Changsha, Hunan). The oven had a heating area of $80 \mathrm{~cm} \times 220 \mathrm{~cm}$ (diameter $\times$ width) and a maximum output of $2.8 \mathrm{~kW}$. A thermocouple was used to measure temperature in the microwave oven. Figure 1 shows the microwave pyrolysis apparatus. The first was connected to the condenser tube, and the second bottle was placed in a dichloromethane solution. 


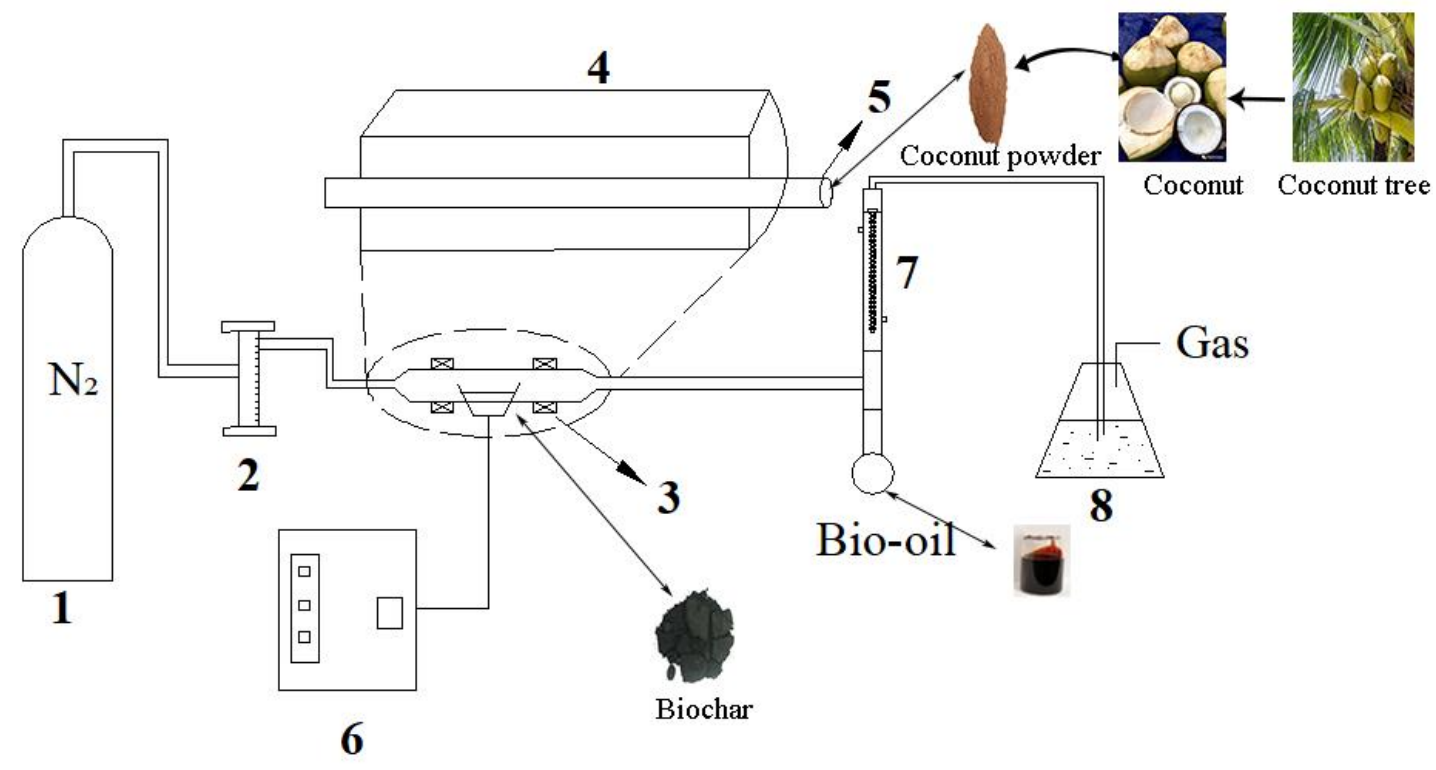

Fig. 1. Systematic illustration of experimental set-up. 1) Nitrogen cylinder; 2) Flowmeter 3) Microwave transmitter 4) Reaction device 5) Quartz tube 6) PID controller 7) Condenser 8) collector

\section{Experimental procedure}

To explore the optimum operating conditions to achieve the most extreme bio-oil yield, pyrolysis experiments of coconut cloth were divided into three sets to examine the influence of operating parameters. The pyrolysis experiments were conducted by placing $20 \mathrm{~g}$ of dry biomass sample in a microwave pyrolysis reactor. Table 1 shows the conditions of experiments conducted for pyrolysis of coconut cloth. The yields of bio-oil and biochar were determined by weighing. The yields of biochar, bio-oil, and pyrolysis gases are given as in Eq. 1, Eq. 2, and Eq. 3, respectively. Each experiment was repeated three times and the average value was determined.

Liquid yield $(\%)=($ Total liquid product weight $/$ Feed weight $) \times 100$

Biochar yield $(\%)=($ Biochar weight $/$ Feed weight $) \times 100$

Gas yield $(\%)=100-($ Liquid yield + Biochar yield $)$

Table 1. Conditions of Experiments Conducted for Pyrolysis of Coconut Cloth

\begin{tabular}{|c|c|c|}
\hline Experiment & $\begin{array}{c}\text { Values of Variable } \\
\text { Parameter }\end{array}$ & $\begin{array}{c}\text { Values of Microwave Parameters } \\
\text { for Verifying Optimum Conditions }\end{array}$ \\
\hline Effect of Temperature $\left({ }^{\circ} \mathrm{C}\right)$ & $450,500,550,600,650$ & $\begin{array}{c}\text { Heating rates: } 20^{\circ} \mathrm{C} / \mathrm{min} \\
\mathrm{N}_{2} \text { flow rate: } 80 \mathrm{~cm}^{3} / \mathrm{min}\end{array}$ \\
\hline $\begin{array}{c}\text { Effect of Heating Rates } \\
\left({ }^{\circ} \mathrm{C} / \mathrm{min}\right)\end{array}$ & $10,15,20,25,30$ & $\begin{array}{c}\text { Temperature: } 550{ }^{\circ} \mathrm{C} \\
\mathrm{N}_{2} \text { flow rate: } 80 \mathrm{~cm}^{3} / \mathrm{min}\end{array}$ \\
\hline $\begin{array}{c}\text { Effect of } \mathrm{N}_{2} \text { Flow Rate } \\
\left(\mathrm{cm}^{3} / \mathrm{min}\right)\end{array}$ & $60,80,100,120$ & $\begin{array}{c}\text { Temperature: } 550^{\circ} \mathrm{C} \\
\text { Heating rates: } 20^{\circ} \mathrm{C} / \mathrm{min}\end{array}$ \\
\hline
\end{tabular}

Note: The heating rate is controllable. The heating rate is the programmed temperature rise heating. A certain heating rate is set to heat from room temperature to a specified temperature and then react at this temperature for a certain time. 


\section{RESULTS AND DISCUSSION}

\section{Characterization of Coconut Cloth}

Table 2 shows the proximate and ultimate analyses of coconut cloth. Moisture content in coconut cloth was low (4.36 wt \%). Coconut cloth biomass powder had higher volatile matter content (72.9 wt \%) and lower ash content (3.98 wt\%), which could result in less loss of fixed carbon for bio-oil during pyrolysis (Buckley 1991; Nayan et al. 2013). Fixed carbon content in coconut cloth was $18.8 \mathrm{wt} \%$. Ultimate analysis showed that coconut cloth had higher amounts of $\mathrm{C}$ and $\mathrm{O}$ than $\mathrm{H}, \mathrm{N}$, and $\mathrm{S}$. Low nitrogen and sulfur content in coconut cloth implied that it released smaller amounts of SOx and NOx durings pyrolysis. With the help of elemental compositions data, the empirical formula of coconut cloth was $\mathrm{CH}_{1.30} \mathrm{O}_{0.59} \mathrm{~N}_{0.01}$. These results were similar to those of other biomass samples (Varma et al. 2019). The $\mathrm{O}$ content plays an important role in determining calorific value (Capunitan and Capareda 2014). In coconut cloth, a higher amount of carbon content than oxygen and ash contents results in a higher HHV of the feedstock (Friedl et al. 2005). The HHV of the feedstock was $18.6 \mathrm{MJ} / \mathrm{kg}$. The hemicellulose, cellulose, and lignin contents of coconut cloth were $34.1 \mathrm{wt} \%, 18.7 \mathrm{wt} \%$, and $35.1 \mathrm{wt} \%$, respectively.

Table 2. Proximate and Ultimate Analyses of Coconut Cloth

\begin{tabular}{|c|c|}
\hline Properties & Coconut Cloth \\
\hline Moisture (wt\%) & 4.36 \\
\hline Volatile Matter (wt\%) & 72.91 \\
\hline Ash Content (wt\%) & 3.98 \\
\hline Fixed Carbon (wt\%) & 18.75 \\
\hline Ultimate Analysis (wt\%) & 47.43 \\
\hline C & 5.12 \\
\hline H & 0.48 \\
\hline N & 37.20 \\
\hline S & 0.84 \\
\hline H/C Molar Ratio & 1.30 \\
\hline O/C Molar Ratio & 0.59 \\
\hline Empirical Formula & $\mathrm{CH}_{1.30} 0 \mathrm{O}_{0.59} \mathrm{~N}_{0.01}$ \\
\hline HHV (MJ/kg) & 18.58 \\
\hline Hemicellulose (wt\%) & 34.10 \\
\hline Cellulose (wt\%) & 18.73 \\
\hline Lignin (wt\%) & 35.09 \\
\hline Other (wt\%) & 12.08 \\
\hline
\end{tabular}

\section{Thermogravimetric analysis of coconut cloth}

The thermal behavior of coconut cloth is shown in Fig. 2. The figure shows that each component of coconut cloth had a different thermal degradation temperature range. The first stage of degradation occurred as temperature increased from $25^{\circ} \mathrm{C}$ to $150{ }^{\circ} \mathrm{C}$. The DTG curve revealed that the first peak appeared at $65.5^{\circ} \mathrm{C}$, in which a small weight loss of $5.26 \%$ occurred due to removal of moisture and light-molecular weight compounds from the coconut cloth sample. The second stage of weight loss was primarily volatilization of an active pyrolysis zone temperature range of $150{ }^{\circ} \mathrm{C}$ to $400{ }^{\circ} \mathrm{C}$ that corresponded with a differential thermal gravimetry (DTG) peak at $329.87^{\circ} \mathrm{C}$, and this stage of weight loss was 
primarily the breakdown of hemicellulose and cellulose molecules present in the biomass due to high decomposition rates. After this, a third stage occurred between $400{ }^{\circ} \mathrm{C}$ and 800 ${ }^{\circ} \mathrm{C}$, but the weight loss rate was minimal. As the temperature increased, the DTG curve tended to be stable when it reached $800{ }^{\circ} \mathrm{C}$, which indicated that the coconut cloth had been completely pyrolyzed. According to literature, hemicellulose and cellulose decomposition occurs at temperature ranges of $150{ }^{\circ} \mathrm{C}$ to $450{ }^{\circ} \mathrm{C}$ and $275{ }^{\circ} \mathrm{C}$ to $450{ }^{\circ} \mathrm{C}$ (Basu 2010), respectively. Higher temperatures favored biochar formation. The purpose of this experiment was to obtain higher yields of bio-oil. Therefore, according to thermogravimetric analyzer (TGA) and DTG curves shown, the pyrolysis temperature range that was optimal for the coconut cloth was $400{ }^{\circ} \mathrm{C}$ to $650{ }^{\circ} \mathrm{C}$.

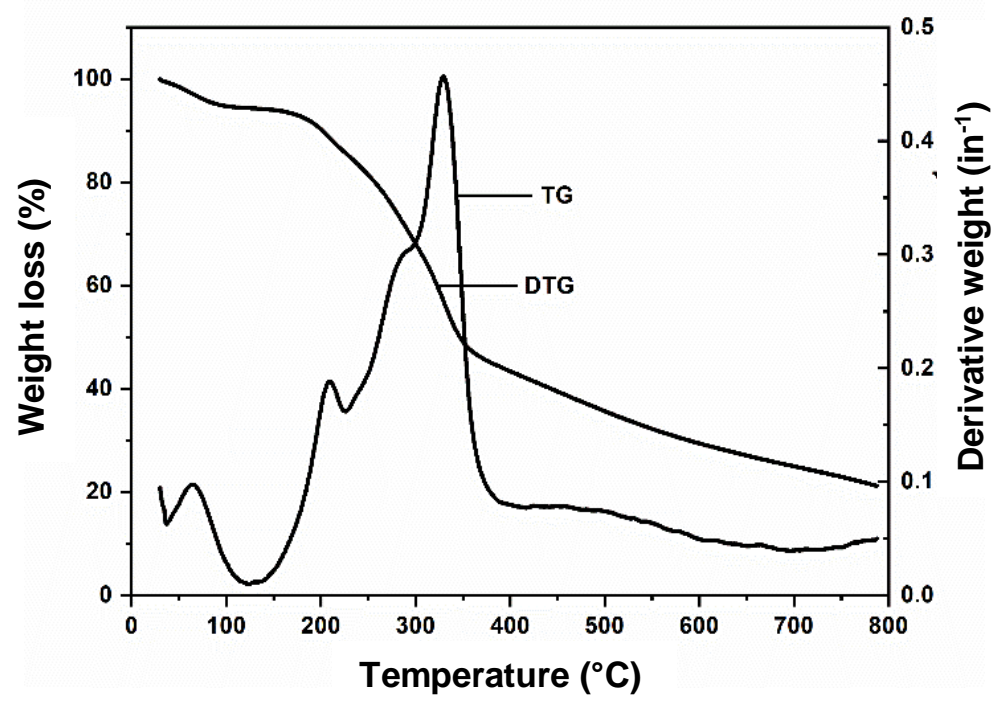

Fig. 2. TG and $D T G$ curves at $10^{\circ} \mathrm{C} / \mathrm{min}$ heating rate

\section{Influence of Pyrolysis Parameters' Effects on Product Yields} Effect of temperature on the products yield

Figure 3 shows the yield distribution of product during pyrolysis obtained at a different carrier gas $\left(\mathrm{N}_{2}\right)$ flow rate of $80 \mathrm{~mL} / \mathrm{min}$. Figure 3 shows that at a heating rate of $20{ }^{\circ} \mathrm{C} / \mathrm{min}$ with the temperature increased from $450{ }^{\circ} \mathrm{C}$ to $550{ }^{\circ} \mathrm{C}$, the yield of bio-oil increased from $35.8 \%$ to $38.3 \%$. At $650{ }^{\circ} \mathrm{C}$, the liquid yield decreased to $36.2 \%$. As the temperature increased, the yield first increased and then decreased. The liquid yield decrease might be due to decomposition of the intermediate compound that noncondensable small molecule gas produced at $550{ }^{\circ} \mathrm{C}$ (Zhang et al. 2007). As the temperature increased, the volatile matter also gradually increased. Due to large cracking of volatile matter of carbon at higher temperatures, the yield of biochar continued to decrease with increasing temperature, and the yield of carbon decreased from $39.3 \%$ to $34.1 \%$. As the temperature gradually increased, some non-condensable gases gradually increased, while the gas and total conversion rate increased (Chutia et al. 2014). The gas yield increased from $24.9 \%$ to $29.7 \%$. According to the above analysis, cracking of coconut cloth at $550{ }^{\circ} \mathrm{C}$ was found to be a suitable temperature. 


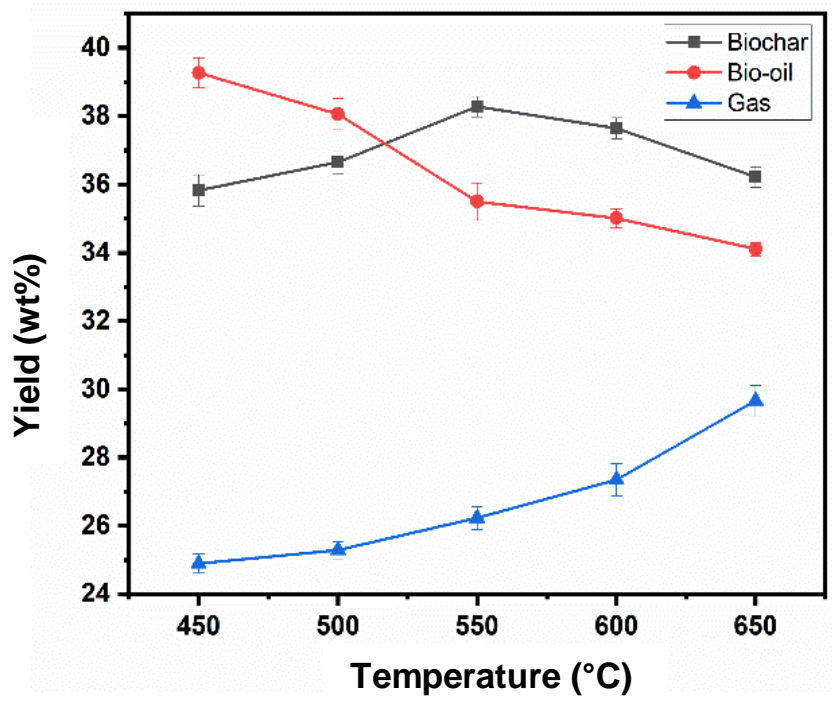

Fig. 3. Yields of pyrolysis products at different pyrolysis temperatures

\section{Effect of heating rates on product yield}

Figure 4 shows the pyrolysis product yields of coconut cloth at different heating rates $\left(10{ }^{\circ} \mathrm{C} / \mathrm{min}, 15^{\circ} \mathrm{C} / \mathrm{min}, 20^{\circ} \mathrm{C} / \mathrm{min}, 25^{\circ} \mathrm{C} / \mathrm{min}\right.$, and $\left.30{ }^{\circ} \mathrm{C} / \mathrm{min}\right)$ at a temperature of $550{ }^{\circ} \mathrm{C}$. The heating rate was increased from $10{ }^{\circ} \mathrm{C} / \mathrm{min}$ to $20{ }^{\circ} \mathrm{C} / \mathrm{min}$, and bio-oil yield increased from $34.7 \%$ to $37.1 \%$. When the heating rate increased from $20{ }^{\circ} \mathrm{C} / \mathrm{min}$ to 30 ${ }^{\circ} \mathrm{C} / \mathrm{min}$, liquid yield was reduced to $34.7 \%$. The increase in bio-oil production was due to the higher heating rate, which reduced the quality and heat transfer limitations and avoided secondary decomposition reactions (Uzun et al. 2010). When the heating rate increased from $10{ }^{\circ} \mathrm{C} / \mathrm{min}$ to $30{ }^{\circ} \mathrm{C} / \mathrm{min}$, carbon yield decreased from $39.6 \%$ to $32.1 \%$ and gas yield increased from $25.7 \%$ to $33.3 \%$. Carbon yields decreased due to faster depolymerization of biomass to predominantly volatiles (Chen et al. 1997). Therefore, at the temperature of $550{ }^{\circ} \mathrm{C}$, the heating rate of $20^{\circ} \mathrm{C} / \mathrm{min}$ was the best choice for liquid yield.

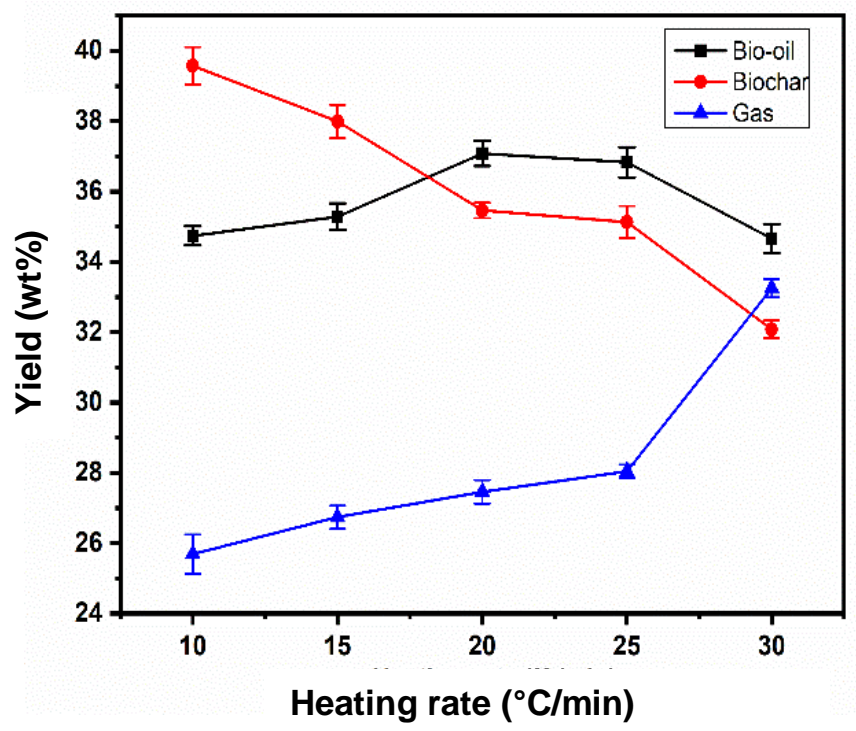

Fig. 4. Effect of heating rate on the yield of pyrolysis products 


\section{Effect of nitrogen flow rate on product yield}

Pyrolysis experiments were performed to investigate the effect of $\mathrm{N}_{2}$ flow rate on product yield, and results are shown in Fig. 5. The effects of four gas flow rates of 60 $\mathrm{cm}^{3} / \mathrm{min}, 80 \mathrm{~cm}^{3} / \mathrm{min}, 100 \mathrm{~cm}^{3} / \mathrm{min}$, and $120 \mathrm{~cm}^{3} / \mathrm{min}$ on pyrolysis yield were studied under the pyrolysis temperature of $550{ }^{\circ} \mathrm{C}$ and the heating rate of $20{ }^{\circ} \mathrm{C} / \mathrm{min}$. With the increase of $\mathrm{N}_{2}$ flow rate, liquid yield reached a maximum of $38.1 \%$ at $80 \mathrm{~cm}^{3} / \mathrm{min}$. When the $\mathrm{N}_{2}$ flow rate was $120 \mathrm{~cm}^{3} / \mathrm{min}$, liquid yield dropped to $35.1 \%$. The biochar yield decreased from $38 \%$ to $34.4 \%$, and gas yield increased from $25.1 \%$ to $30.5 \%$. At lower $\mathrm{N}_{2}$ flow rates, volatiles residence times were longer, which resulted in the formation of more biochar. As flow rate of $\mathrm{N}_{2}$ increased, more steam formation occurred, with the result that biochar yield decreased as gas yield increased.

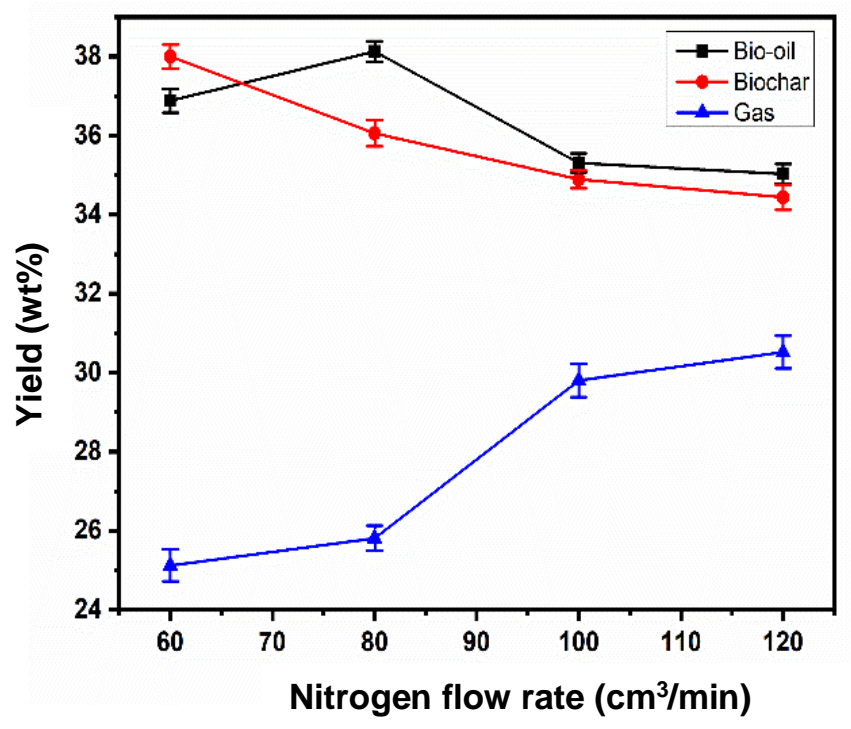

Fig. 5. Effect of nitrogen flow rate on yield of pyrolysis products

\section{Characteristics of Bio-oil}

Table 3. Elemental Composition and Physical Properties of Bio-oil

\begin{tabular}{|c|c|}
\hline Physical Properties & Value \\
\hline Colour & Dark Brown \\
\hline Water Content (wt $\%$ ) & 13.47 \\
\hline Kinematic Viscosity, $40^{\circ} \mathrm{C}, \mathrm{cSt}$ & 20.51 \\
\hline $\mathrm{pH}$ & 3.69 \\
\hline Elemental Composition (wt\%) & \\
\hline Carbon & 59.89 \\
\hline Hydrogen & 7.2 \\
\hline Nitrogen & 1.14 \\
\hline Oxygen & 29.55 \\
\hline Sulfur & 0 \\
\hline H/C Molar Ratio & 1.44 \\
\hline O/C Molar Ratio & 0.37 \\
\hline Empirical Formula & $\mathrm{CH}_{1.44} \mathrm{O}_{0.37} \mathrm{~N}_{0.02}$ \\
\hline HHV (MJ/kg) & 26.45 \\
\hline
\end{tabular}


Table 3 lists the elemental composition, physical properties, calorific value, and empirical formula of bio-oil. The water content was $13.5 \mathrm{wt} \%$. The viscosity was $20.5 \mathrm{cSt}$. Bio-oils contain substantial amounts of organic acids, mostly acetic and formic acid, which resulted in a $\mathrm{pH}$ of 3.69. Calorific value of liquid fuel is an important property, as it signifies the energy value. The higher heating value of bio-oil was $26.4 \mathrm{MJ} / \mathrm{kg}$. Nitrogen content of the bio-oil was more than the precursors of all biomass and biochar, which indicated that nitrogen remained in the liquid product during pyrolysis. The sulfur content was not found in bio-oil. The sulfur-free organic phase is one of the advantages of bio-oil for fuel applications. Therefore, bio-oil could be further processed and upgraded to directly replace fossil fuels (Venderbosch and Prins 2010). The $\mathrm{H} / \mathrm{C}$ and $\mathrm{O} / \mathrm{C}$ molar ratios of bio-oil were 1.44 and 0.37, respectively. The empirical formula for bio-oil was $\mathrm{CH}_{1.44} \mathrm{O}_{0.37} \mathrm{~N}_{0.02}$.

\section{FTIR analysis of bio-oil}

The biomass pyrolysis oil component is complex, and the extracted liquid product contains a mixture of various unknown compounds. Various functional groups present in the bio-oil were detected in the FTIR spectrum. From Fig. 6 and Table 4, the strong absorption peak between $3500 \mathrm{~cm}^{-1}$ and $3200 \mathrm{~cm}^{-1}$ was the result of the presence of the O$\mathrm{H}$ group. The absorption peak at $3446 \mathrm{~cm}^{-1}$ indicates the presence of carboxylic acids, phenols, and alcohols (Chen et al. 2016). The C-H stretching vibrations between $3000 \mathrm{~cm}^{-}$ 1 and $2800 \mathrm{~cm}^{-1}$ indicated the presence of aliphatic $\mathrm{CH}_{3}$ and $\mathrm{CH}_{2}$. The N-H stretching vibration peak at $2361 \mathrm{~cm}^{-1}$ indicated the presence of tertiary ammonium salt. The peak at $1645 \mathrm{~cm}^{-1}$ representing the $\mathrm{C}=\mathrm{O}$ stretching vibration was indicative of ketone, quinone, aldehyde groups, etc. The peaks at $1511 \mathrm{~cm}^{-1}$ and $1454 \mathrm{~cm}^{-1}$ indicated the presence of $\mathrm{C}=\mathrm{C}$ bonds of alkene and aromatics in pyrolysis bio-oil, respectively. The absorption peaks at $1270 \mathrm{~cm}^{-1}$ and $1112 \mathrm{~cm}^{-1}$ indicated the presence of a high amount of oxygenated compounds in the forms of alcohol and ether.

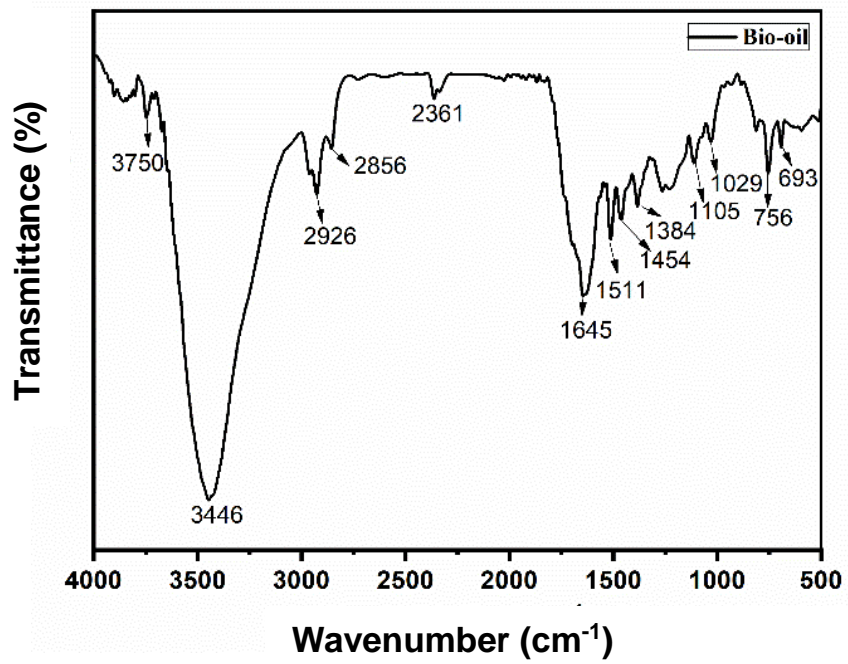

Fig. 6. FTIR spectrum of coconut cloth bio-oil

The bio-oil contained aromatic compounds, as confirmed by a C-H plane benching vibration between $700 \mathrm{~cm}^{-1}$ and $900 \mathrm{~cm}^{-1}$. Therefore, it could be concluded that the bio-oil form contained ethers, alcohols, phenols, etc. A mixture of valuable organic compounds 
could be upgraded into valuable liquid fuels. Further understanding of specific substances contained in the bio-oil was determined by ${ }^{1} \mathrm{HNMR}$ and GC-MS.

Table 4. FTIR Peak Details of Obtained Bio-oil

\begin{tabular}{|c|c|c|}
\hline Wavenumber $\left(\mathrm{cm}^{-1}\right)$ & Functional Groups & Probable Compound \\
\hline 3500 to 3200 & O-H stretching & Phenols, alcohols \\
\hline 3000 to 2800 & C-H stretching & Alkanes \\
\hline 1645 & C=O stretching & Ketones, aldehyde \\
\hline 1511,1454 & C=C stretching & $\begin{array}{c}\text { Olefins, aromatic } \\
\text { hydrocarbons }\end{array}$ \\
\hline 1384 & C-H stretching & Alkenes \\
\hline 1270 & C-O stretching & Phenols, esters \\
\hline 1105 to 1029 & C-O stretch & Ethers, esters \\
\hline 700 to 900 & C-H in plane benching & Aromatics \\
\hline
\end{tabular}

GC-MS analysis of bio-oil

The GC-MS analysis of the bio-oil showed that the organic substances found in liquid products were ketones, acids, aldehydes, esters, and phenols.

Table 5. GC-MS Analysis of Pyrolysis Liquid

\begin{tabular}{|c|c|c|c|c|}
\hline No. & $\begin{array}{l}\text { Relative } \\
\text { Time (min) }\end{array}$ & Peak Name & $\begin{array}{l}\text { Molecular } \\
\text { Formula }\end{array}$ & Area (\%) \\
\hline 1 & 2.201 & Methyl acetate & $\mathrm{C}_{3} \mathrm{H}_{6} \mathrm{O}$ & 0.34 \\
\hline 2 & 3.804 & 1H-Pyrazole, 1,3-dimethyl- & $\mathrm{C}_{5} \mathrm{H}_{8} \mathrm{~N}_{2}$ & 1.21 \\
\hline 3 & 6.355 & 2-Cyclopenten-1-one & $\mathrm{C}_{5} \mathrm{H}_{6} \mathrm{O}$ & 0.57 \\
\hline 4 & 6.5 & 2-Cyclopenten-1-one, 2-methyl- & $\mathrm{C}_{6} \mathrm{H}_{8} \mathrm{O}$ & 0.58 \\
\hline 5 & 7.632 & Acetic acid & $\mathrm{C}_{2} \mathrm{H}_{4} \mathrm{O}$ & 3.96 \\
\hline 6 & 7.777 & 3-Furaldehyde & $\mathrm{C}_{5} \mathrm{H}_{10} \mathrm{O}_{2}$ & 1.96 \\
\hline 7 & 8.657 & 2-Cyclopenten-1-one, 3-methyl- & $\mathrm{C}_{6} \mathrm{H}_{8} \mathrm{O}$ & 0.82 \\
\hline 8 & 8.931 & $\begin{array}{l}\text { 2-Cyclopenten-1-one, 2,3- } \\
\text { dimethyl- }\end{array}$ & $\mathrm{C}_{7} \mathrm{H}_{10} \mathrm{O}$ & 0.80 \\
\hline 9 & 9.374 & 2-Furancarboxaldehyde, 5-methyl- & $\mathrm{C}_{6} \mathrm{H}_{10} \mathrm{O}_{2}$ & 1.60 \\
\hline 10 & 12.92 & $\begin{array}{l}\text { 2-Cyclopenten-1-one, 2-hydroxy-3- } \\
\text { methyl- }\end{array}$ & $\mathrm{C}_{5} \mathrm{H}_{8} \mathrm{O}_{2}$ & 0.75 \\
\hline 11 & 13.347 & Phenol, 2-methoxy- & $\mathrm{C}_{7} \mathrm{H}_{8} \mathrm{O}_{2}$ & 8.31 \\
\hline 12 & 13.775 & $\begin{array}{l}\text { 2-Cyclopenten-1-one, 3-ethyl-2- } \\
\text { hydroxy- }\end{array}$ & $\mathrm{C}_{7} \mathrm{H}_{10} \mathrm{O}_{2}$ & 0.72 \\
\hline 13 & 14.588 & Creosol & $\mathrm{C}_{8} \mathrm{H}_{10} \mathrm{O}_{2}$ & 2.85 \\
\hline 14 & 14.732 & Maltol & $\mathrm{C}_{6} \mathrm{H}_{6} \mathrm{O}_{3}$ & 0.92 \\
\hline 15 & 15.169 & Phenol, 2-methyl- & $\mathrm{C}_{7} \mathrm{H}_{8} \mathrm{O}$ & 4.34 \\
\hline 16 & 15.237 & Phenol & $\mathrm{C}_{6} \mathrm{H}_{6} \mathrm{O}$ & 42.99 \\
\hline 17 & 15.505 & Phenol, 4-ethyl-2-methoxy- & $\mathrm{C}_{9} \mathrm{H}_{10} \mathrm{O}_{2}$ & 4.11 \\
\hline 18 & 16.071 & Phenol, 2,3-dimethyl- & $\mathrm{C}_{8} \mathrm{H}_{10} \mathrm{O}$ & 0.83 \\
\hline 19 & 16.114 & Phenol, 2,4-dimethyl- & $\mathrm{C}_{8} \mathrm{H}_{10} \mathrm{O}$ & 0.70 \\
\hline 20 & 16.157 & $\mathrm{p}$-Cresol & $\mathrm{C}_{7} \mathrm{H}_{4} \mathrm{O}$ & 7.23 \\
\hline 21 & 16.259 & Phenol, 3-methyl- & $\mathrm{C}_{7} \mathrm{H}_{8} \mathrm{O}$ & 2.73 \\
\hline 22 & 17.253 & Phenol, 4-ethyl- & $\mathrm{C}_{8} \mathrm{H}_{8} \mathrm{O}$ & 3.62 \\
\hline 23 & 18.259 & Phenol, 2,6-dimethoxy- & $\mathrm{C}_{8} \mathrm{H}_{10} \mathrm{O}_{3}$ & 3.76 \\
\hline 24 & 19.198 & 3-Allyl-6-methoxyphenol & $\mathrm{C}_{10} \mathrm{H}_{10} \mathrm{O}_{2}$ & 2.86 \\
\hline 25 & 28.13 & n-Hexadecanoic acid & $\mathrm{C}_{16} \mathrm{H}_{32} \mathrm{O}_{2}$ & 2.58 \\
\hline
\end{tabular}


The phenols in the bio-oil included phenol, 3-methylphenol, 4-ethylphenol, and 2,6-2-methoxyphenogh content of phenols was attributed to the degradation of $35.1 \%$ lignin in the coconut cloth. Phenols are also an important organic chemical raw material and have important applications in the pharmaceutical, synthetic fiber, perfume, pesticide, and other industries. Phenolic derivatives play a key role in the chemical industry and are also important synthetic materials in organic chemistry. In this study of coconut cloth as a raw material, bio-oil obtained with high concentrations of phenol and phenolic compounds was feasible, which showed that bio-oil has great potential in the chemical industry.

\section{${ }^{1}$ HNMR analysis of bio-oil}

It was necessary to obtain evidence about the type of protons present in the bio-oil via the ${ }^{1} \mathrm{HNMR}$ spectrum. Figure 7 shows the ${ }^{1} \mathrm{HNMR}$ range of bio-oil.

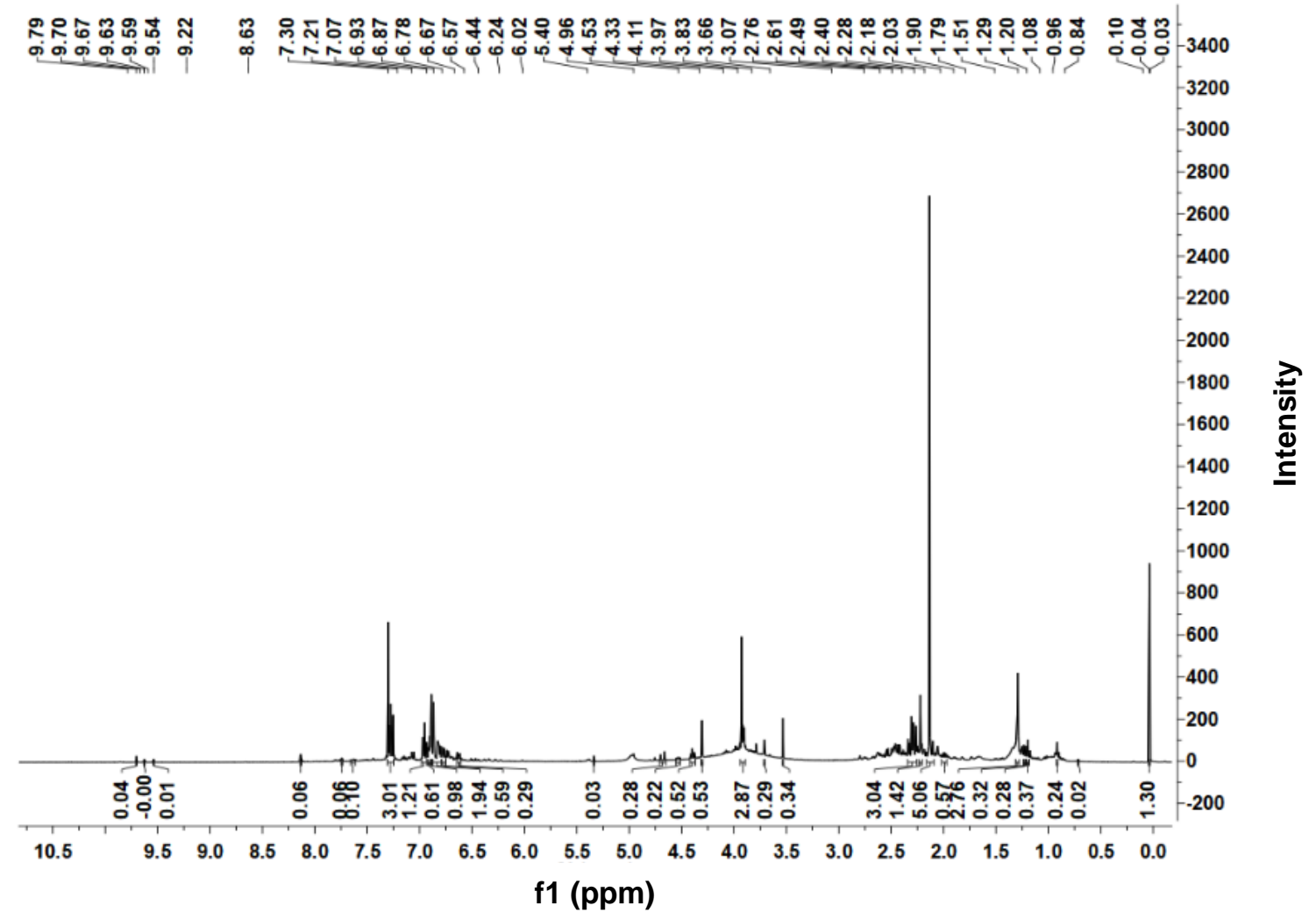

Fig. 7. HNMR spectrum of bio-oil

The ${ }^{1}$ HNMR spectra of the bio-oil are presented in Table 6 with the respective integral values of selected regions of spectra on a percentage basis. In the spectrum, $28.26 \%$ of protons in the region between $0.5 \mathrm{ppm}$ to $1.5 \mathrm{ppm}$ were attributed to aliphatic protons (Bordoloi et al. 2015). In the range of $1.5 \mathrm{ppm}$ to $3.0 \mathrm{ppm}(26.67 \%), \mathrm{CH}_{3}, \mathrm{CH}_{2}$, and $\mathrm{CH}$ protons present in alpha or further from an aromatic ring resonate was due to the aromatic ring resonate. The resonance of the proton in the $3.0 \mathrm{ppm}$ to $4.5 \mathrm{ppm}$ interval was due to the proton of the methylene group attached to the aromatic ring, or due to the presence of amine and alcohol protons, where the area occupied by protons was $26.7 \%$ (Saikia et al. 2015). The integral region between $4.5 \mathrm{ppm}$ and $6.0 \mathrm{ppm}$ was due to protons of phenolic $(\mathrm{OH})$ and olefinic protons $(0.68 \%)$. Finally, in the $6.0 \mathrm{ppm}$ to $9.0 \mathrm{ppm}$ region, the protons 
of the aromatic ring area was $31.9 \%$. From the above analysis, bio-oil contained phenols, alcohols, and acids, which was consistent with FTIR and GC-MS studies.

Table 6. ${ }^{1}$ HNMR Results of Bio-oil

\begin{tabular}{|c|c|c|}
\hline $\begin{array}{c}\text { Chemical Shift } \\
\text { (ppm) }\end{array}$ & Hydrogen Type & $\begin{array}{c}\text { Bio-oil (mol\% of Total } \\
\text { Hydrogen) }\end{array}$ \\
\hline 0.5 to 1.5 & $\begin{array}{c}\text { Aliphatic }\left(\mathrm{CH}_{3} \gamma, \beta-\mathrm{CH}_{3}, \mathrm{CH}_{2} \text {, and } \mathrm{CH} \text { or }\right. \\
\text { further from an aromatic ring) }\end{array}$ & 28.22 \\
\hline 1.5 to 3.0 & $\begin{array}{c}\mathrm{CH}_{3}, \mathrm{CH}_{2} \text {, and } \mathrm{CH}_{\beta} \text { to an aromatic ring } \\
\text { (naphthenic) }\end{array}$ & 26.67 \\
\hline 3.0 to 4.5 & Ring-join methylene $\left(\mathrm{Ar}-\mathrm{CH}_{2}-\mathrm{Ar}\right)$ & 12.55 \\
\hline 4.5 to 6.0 & Phenolic $(\mathrm{OH}$ ) or olefinic proton & 0.687 \\
\hline 6.0 to 9.0 & Aromatic & 31.87 \\
\hline
\end{tabular}

\section{Characterization of Biochar}

Proximate and ultimate analysis of biochar

The proximate and ultimate analysis compositions of biochar are presented in Table 7. The biochar contained higher carbon content and less oxygen content than the feedstock. Due to the high carbon content and low ash and volatile contents of biomass char, highquality biochar with a high calorific value and a large amount of fixed carbon was obtained (Chaiwong et al. 2013). There was a remarkable increase of calorific value from the original biomass $(18.6 \mathrm{MJ} / \mathrm{kg})$ to the biochar $(27.8 \mathrm{MJ} / \mathrm{kg})$. When the pyrolysis temperature was $550{ }^{\circ} \mathrm{C}, \mathrm{pH}$ of the biomass biochar was in a highly alkaline region, which could be used to repair soil by neutralizing soil acidity and increasing soil $\mathrm{pH}$. Biochar had lower $\mathrm{O} / \mathrm{C}$ and $\mathrm{H} / \mathrm{C}$ ratios and less energy loss, smoke, and water vapor in the combustion process, which can result in high-quality biochar fuels (Zhang et al. 2017). In general, an O/C ratio lower than 0.2 signified a biochar half-life of 1000 years at minimum, which showed that thermal stability of biochar was very good.

Table 7. Proximate and Ultimate Analysis of Biochar

\begin{tabular}{|c|c|}
\hline Properties & Biochar \\
\hline Moisture (wt\%) & 1.86 \\
\hline Volatile Matter (wt\%) & 11.44 \\
\hline Ash Content (wt\%) & 8.48 \\
\hline Fixed Carbon (wt\%) & 78.22 \\
\hline \multicolumn{2}{|c|}{ Ultimate Analysis (wt\%) } \\
\hline C & 76.88 \\
\hline N & 2.07 \\
\hline O & 0.51 \\
\hline S & 7.21 \\
\hline H/C Molar Ratio & 0.78 \\
\hline O/C Molar Ratio & 0.32 \\
\hline Empirical Formula & 0.07 \\
\hline pH & $\mathrm{CH}_{0.32} 0 \mathrm{O}_{0.07} \mathrm{~N}_{0.01}$ \\
\hline HHV (MJ/kg) & 10.20 \\
\hline & 27.77 \\
\hline
\end{tabular}




\section{FTIR analysis of biochar}

Biochar was characterized by FTIR, which is shown in Fig. 8. The stretching vibration peak of $\mathrm{O}-\mathrm{H}$ in the range of $3600 \mathrm{~cm}^{-1}$ and $3200 \mathrm{~cm}^{-1}$ might have been due to the release of a large amount of moisture. The $2919 \mathrm{~cm}^{-1}$ weak peak was due to the stretching vibration of aliphatic $\mathrm{CH}_{3}$. A moderate-intensity absorption peak at $1587 \mathrm{~cm}^{-1}$ revealed the presence of an aromatic skeleton vibration, which demonstrated the presence of lignin at this position. A strong peak at $1422 \mathrm{~cm}^{-1}$ indicates a representative aromatic $\mathrm{C}=\mathrm{O}$ and $\mathrm{C}=\mathrm{C}$ functional group (Aboulkas et al. 2017). The peak between $1200 \mathrm{~cm}^{-1}$ and $900 \mathrm{~cm}^{-1}$ indicated aromatic $\mathrm{C}-\mathrm{O}$ stretching vibration and the presence of oxygen-containing functionality in the biochar. In the range of $600 \mathrm{~cm}^{-1}$ to $900 \mathrm{~cm}^{-1}$, there was a stretching vibration peak of aromatic $\mathrm{C}-\mathrm{H}$, which indicates the presence of an adjacent aromatic hydrogen component in the biochar (Yakkala et al. 2013).

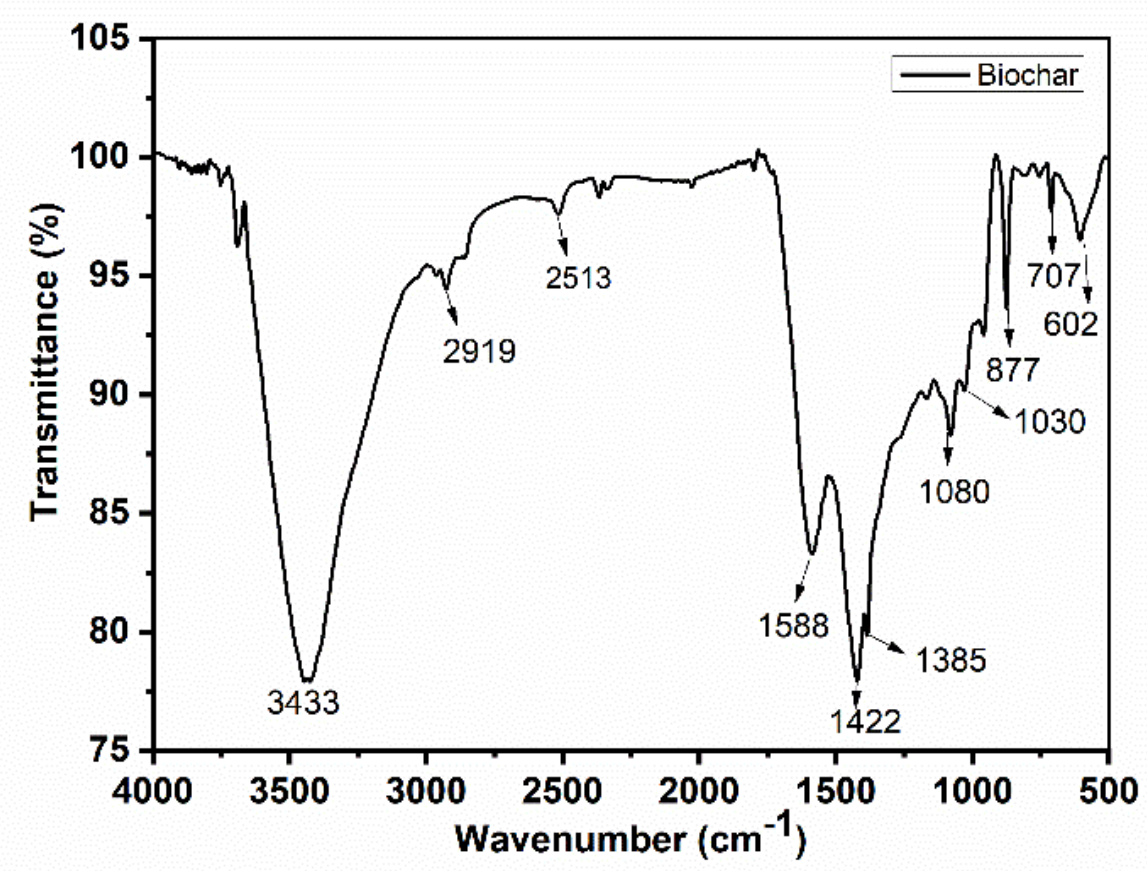

Fig. 8. FTIR spectra of biochar

\section{SEM-EDX analysis of biochar}

The SEM-EDX characterization method was used to study the morphological characteristics of coconut cloth and biochar. From Fig. 9(a) and Fig. 9(c), the SEM images of coconut cloth and biochar showed a great difference between their sample images. The interior of the coconut cloth was made of lignocellulose, which was almost filled and had a smooth surface. The morphology of biochar and its appearance on the surface left a rough appearance, which could be a honeycomb structure that showed more void space and porosity and helped improve adsorption capacity. From the EDX analysis in Fig. 9(b), the raw coconut cloth was mainly composed of high concentrations of $\mathrm{C}(59.03 \%)$ and $\mathrm{O}$ $(40.97 \%)$. Figure $9(\mathrm{~d})$ showed that the biomass carbon contained $\mathrm{Cl}(0.83 \%), \mathrm{K}(1.04 \%)$, $\mathrm{Na}(0.70 \%)$, and other elements, which are important inorganic nutrients for soil fertility and crop production. 

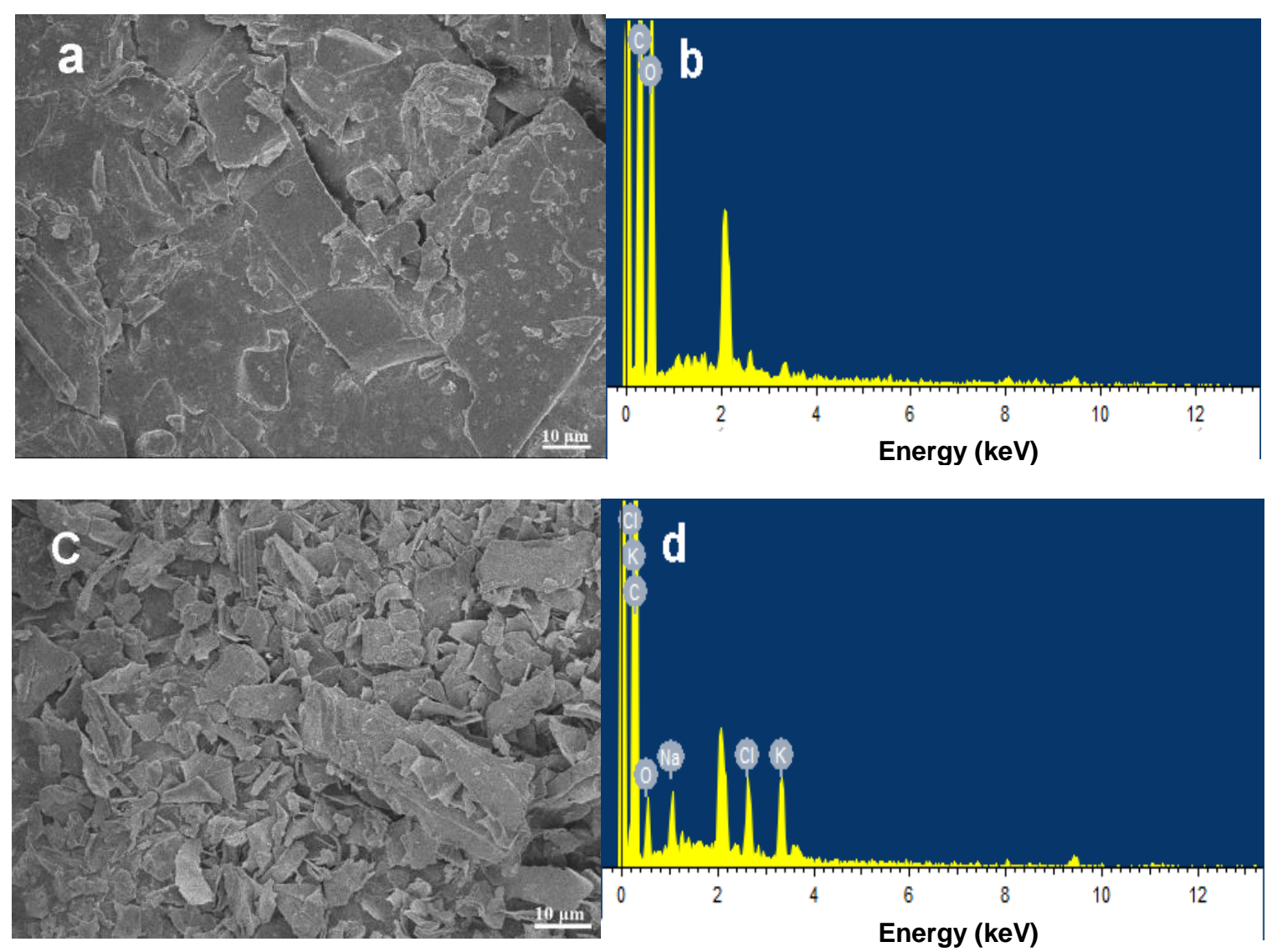

Fig. 9. SEM-EDX analysis of coconut cloth $(a, b)$ and biochar $(\mathrm{c}, \mathrm{d})$ at $550^{\circ} \mathrm{C}$

$X$-ray analysis of biochar

X-ray diffraction was analyzed, and biomass crystallinity and biochar structure are given in Fig. 10. The coconut cloth showed a sharp peak at $2 \theta \mathrm{ca} .22^{\circ}$, which indicated the presence of crystals and amorphous matter. Pyrolysis of biochar weakened the $22^{\circ}$ peak, and the appearance of some new peaks $\left(28.1^{\circ}, 40.7^{\circ}, 50.1^{\circ}\right.$, and $\left.66.3^{\circ}\right)$ indicated the degradation of cellulose and the appearance of an amorphous organic phase (Wang et al. 2009). The crystal phase present in the biochar was converted into an amorphous phase by pyrolysis, so the crystallization peak disappeared in the biochar (Varma et al. 2019).
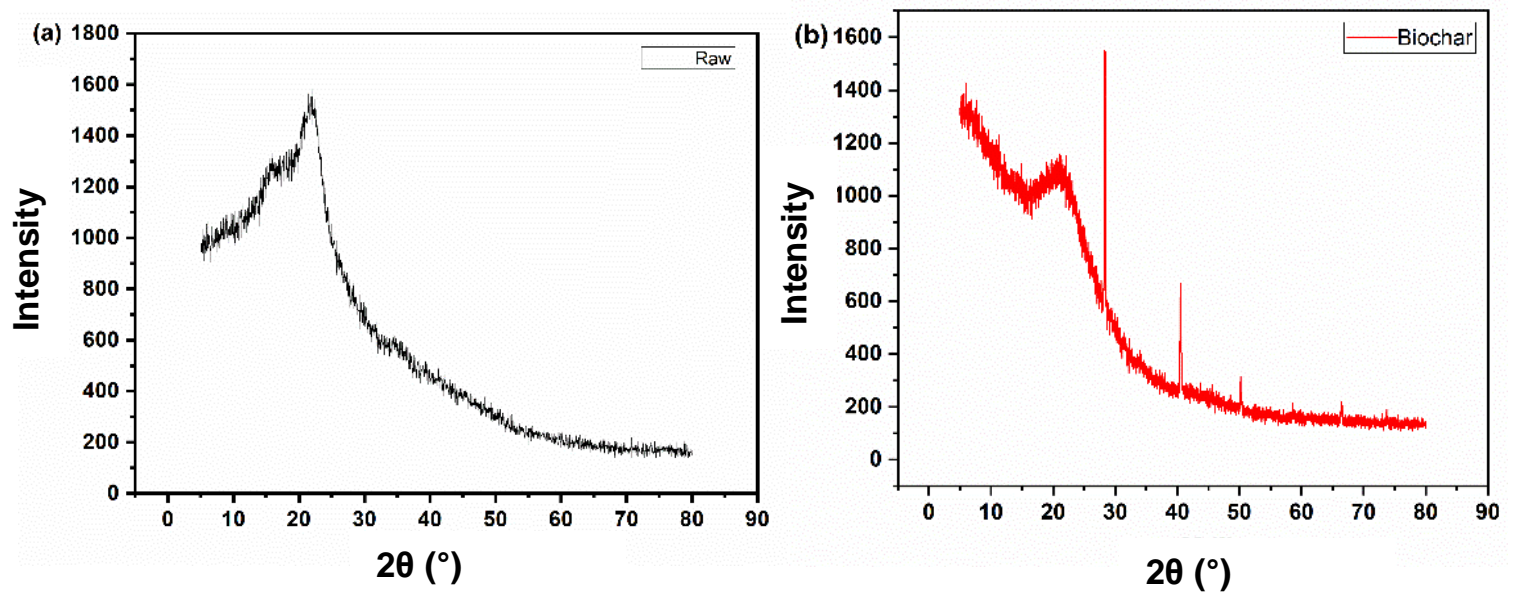

Fig. 10. X-ray diffraction analysis ot coconut cloth and biochar 
Typical composition of products obtained from different feedstock

Table 8 summarizes the optimum pyrolysis condition of the pyrolysis products properties. It can be observed from Table 8 that the best pyrolysis temperature, heating rate, and $\mathrm{N}_{2}$ flow rate were $550{ }^{\circ} \mathrm{C}, 20^{\circ} \mathrm{C} / \mathrm{min}$, and $80 \mathrm{~cm}^{3} / \mathrm{min}$, respectively. It is also evident that for different biomass raw material and pyrolysis processes, and the calorific value of the products (bio-oil and biochar) and the content of phenolic derivatives of bio-oil are different.

Table 8. Characterization of Coconut Cloth Pyrolysis Oil and Literature Comparison

\begin{tabular}{|c|c|c|c|c|c|c|}
\hline $\begin{array}{l}\text { Feed- } \\
\text { stock }\end{array}$ & $\begin{array}{l}\text { Reactor } \\
\text { type }\end{array}$ & Pyrolysis conditions & $\begin{array}{l}\text { Bio-oil } \\
\mathrm{HHV} \\
\mathrm{MJ} / \mathrm{kg}\end{array}$ & $\begin{array}{c}\text { Biochar } \\
\mathrm{HHV} \\
\mathrm{MJ} / \mathrm{kg}\end{array}$ & $\begin{array}{l}\text { Phenolic } \\
\text { derivatives } \\
\text { content } \%\end{array}$ & Ref \\
\hline $\begin{array}{l}\text { Coconut } \\
\text { cloth }\end{array}$ & Microwave & $\begin{array}{c}\text { Temperature: } 5500^{\circ} \mathrm{C} \\
\text { Heating rate: } 20^{\circ} \mathrm{C} / \mathrm{min} \\
\mathrm{N}_{2} \text { flow rate } 80 \mathrm{~cm}^{3} / \mathrm{min}\end{array}$ & 26.45 & 27.77 & $79.57 \%$ & Present study \\
\hline $\begin{array}{l}\text { Corn } \\
\text { stalk }\end{array}$ & Microwave & $\begin{array}{c}\text { Temperature: } 200^{\circ} \mathrm{C} \\
\text { Heating rate: - } \\
\mathrm{N}_{2} \text { flow rate: - }\end{array}$ & 2.47 & 32 & $60 \%$ & $\begin{array}{c}\text { (Salema et al. } \\
\text { 2017) }\end{array}$ \\
\hline $\begin{array}{c}\text { Coconut } \\
\text { shell }\end{array}$ & $\begin{array}{l}\text { Semi } \\
\text { batch }\end{array}$ & $\begin{array}{c}\text { Temperature: } 575^{\circ} \mathrm{C} \\
\text { Heating rate: } 20^{\circ} \mathrm{C} / \mathrm{min} \\
\mathrm{N}_{2} \text { flow rate: - }\end{array}$ & 19.75 & 23.68 & $66.87 \%$ & $\begin{array}{c}\text { (Rout et al. } \\
\text { 2016) }\end{array}$ \\
\hline $\begin{array}{c}\text { Wood } \\
\text { sawdust }\end{array}$ & $\begin{array}{l}\text { Semi } \\
\text { batch }\end{array}$ & $\begin{array}{l}\text { Temperature: } 500^{\circ} \mathrm{C} \\
\text { Heating rate: } 50^{\circ} \mathrm{C} / \mathrm{min} \\
\mathrm{N}_{2} \text { flow rate: } 100 \mathrm{~cm}^{3} / \mathrm{min}\end{array}$ & 27.82 & 22.03 & $46.62 \%$ & $\begin{array}{c}\text { (Anil et al. } \\
\text { 2019) }\end{array}$ \\
\hline $\begin{array}{l}\text { Alligator } \\
\text { weed }\end{array}$ & Fixed bed & $\begin{array}{l}\text { Temperature: } 450^{\circ} \mathrm{C} \\
\text { Heating rate: } 25^{\circ} \mathrm{C} / \mathrm{min} \\
\mathrm{N}_{2} \text { flow rate: } 20 \mathrm{~cm}^{3} / \mathrm{min}\end{array}$ & 8.88 & 20.41 & $16.55 \%$ & $\begin{array}{c}\text { (Bhattacharjee } \\
\text { and Biswas } \\
\text { 2017) }\end{array}$ \\
\hline $\begin{array}{c}\text { Teak } \\
\text { sawdust }\end{array}$ & $\begin{array}{l}\text { tubular } \\
\text { packed } \\
\text { bed }\end{array}$ & \begin{tabular}{|c|} 
Temperature: $600^{\circ} \mathrm{C}$ \\
Heating rate: - \\
$\mathrm{N}_{2}$ flow rate: $150 \mathrm{~cm}^{3} / \mathrm{min}$
\end{tabular} & 25.83 & 28.19 & $22.75 \%$ & $\begin{array}{c}\text { (Goutam et al. } \\
2019)\end{array}$ \\
\hline $\begin{array}{l}\text { Napier } \\
\text { Grass }\end{array}$ & Fix bed & \begin{tabular}{|c|} 
Temperature: $600^{\circ} \mathrm{C}$ \\
Heating rate: - \\
$\mathrm{N}_{2}$ flow rate: $30 \mathrm{~cm}^{3} / \mathrm{min}$
\end{tabular} & 28.50 & 27.60 & $27.1 \%$ & $\begin{array}{c}\text { (Isah et al. } \\
\text { 2015) }\end{array}$ \\
\hline $\begin{array}{c}\text { Orange } \\
\text { bagasse }\end{array}$ & $\begin{array}{l}\text { Semi } \\
\text { batch }\end{array}$ & $\begin{array}{l}\text { Temperature: } 525^{\circ} \mathrm{C} \\
\text { Heating rate: } 75^{\circ} \mathrm{C} / \mathrm{min} \\
\mathrm{N}_{2} \text { flow rate: } 20 \mathrm{~cm}^{3} / \mathrm{min}\end{array}$ & 21.72 & 27.67 & $27.41 \%$ & $\begin{array}{c}\text { (Bhattacharjee } \\
\text { and Biswas } \\
2017 \text { ) }\end{array}$ \\
\hline
\end{tabular}


Table 8 shows that different raw materials and different pyrolysis instruments of the products have different properties. The phenolic derivatives content of the bio-oil obtained under the optimal conditions of the raw materials in this study is significantly higher than other biomass raw materials. It seems that the present process is competitive with others (Table 8).

\section{CONCLUSIONS}

1. In this study, the pyrolysis experiments of coconut cloth were performed in an inert atmosphere $\left(\mathrm{N}_{2}\right)$ in a microwave reactor. The experimental results showed that at a temperature of $550{ }^{\circ} \mathrm{C}$, a heating rate of $20^{\circ} \mathrm{C} / \mathrm{min}$, and an $\mathrm{N}_{2}$ flow rate of $80 \mathrm{~mL} / \mathrm{min}$, the maximum yield of bio-oil was $38.3 \%$.

2. The obtained bio-oil phenol content was $39.0 \%$, and the total phenolic content was $79.6 \%$ via the GC-MS area normalization method.

3. The bio-oil and biochar had high calorific values due to their higher carbon content and lower oxygen content compared to biomass, so they could be used as renewable fuel.

4. From the above studies, it was concluded that coconut cloth was potential renewable fuel for pyrolysis.

\section{ACKNOWLEDGMENTS}

This work was supported by the Hainan Provincial Key Projects (ZDYF2018134) and the College of Chemical Engineering, Hainan University, Haikou, Hainan, China. The authors are grateful for the valuable comments from the reviewers and editors to improve the quality of this paper.

\section{REFERENCES CITED}

ASTM D3172-07 (2007). "Standard practice for proximate analysis of coal and coke," ASTM International, West Conshohocken, PA, USA.

ASTM D4486-10 (2010). "Standard test method for kinematic viscosity of volatile and reactive liquids," ASTM International, West Conshohocken, PA, USA.

Aboulkas, A., Hammani, H., El Achaby, M., Bilal, E., Barakat, A., and El Harfi, K. (2017). "Valorization of algal waste via pyrolysis in a fixed-bed reactor: Production and characterization of bio-oil and bio-char," Bioresource Technol. 243, 400-408. DOI: 10.1016/j.biortech.2017.06.098

Anil, K. V., Lokendra, S. T., Ravi S., and Prasenjit M. (2019). "Pyrolysis of wood sawdust: Effects of process parameters on products yield and characterization of products," Waste Management. 89, 224-235. DOI: 10.1016/j.wasman.2019.04.016

Basu, P. (2010). "Biomass gasification and pyrolysis - Practical design and theory," Comprehensive Renewable Energy. 25(2), 133-153. DOI: 10.1016/B978-0-08087872-0.00514-X 
Buckley, T. J. (1991). “Calculation of higher heating values of biomass materials and waste components from elemental analyses," Resour. Conserv. Recy. 5(4), 329-341. DOI: 10.1016/0921-3449(91)90011-c

Bordoloi, N., Narzari, R., Chutia, R. S., Bhaskar, T., and Kataki, R. (2015). "Pyrolysis of Mesua ferrea and Pongamia glabra seed cover: Characterization of bio-oil and its subfractions," Bioresource Technol. 178, 83-89. DOI: 10.1016/j.biortech.2014.10.079

Bhattacharjee, N., and Biswas, A. B. (2017). "Pyrolysis of Alternanthera philoxeroides (alligator weed): Effect of pyrolysis parameter on product yield and characterization of liquid product and bio char," Journal of the Energy Institute, DOI : 10.1016/j.joei.2017.02.011

Cai, Y., Fan, Y., Li, X., Chen, L., and Wang, J. (2016). "Preparation of refined bio-oil by catalytic transformation of vapors derived from vacuum pyrolysis of rape straw over modified HZSM-5," Energy 102, 95-105. DOI: 10.1016/j.energy.2016.02.051

Capunitan, J. A., and Capareda, S. C. (2014). "Hydrotreatment of corn stover bio-oil using noble metal catalysts," Fuel Process. Technol. 125, 190-199. DOI: 10.1016/j.fuproc.2014.03.029

Chaiwong, K., Kiatsiriroat, T., Vorayos, N., and Thararax, C. (2013). "Study of bio-oil and bio-char production from algae by slow pyrolysis," Biomass Bioenerg. 56, 600606. DOI: 10.1016/j.biombioe.2013.05.035

Chen, G., Yu, Q., and Sjöström, K. (1997). "Reactivity of char from pyrolysis of birch wood,” J. Anal. Appl. Pyrol. 40-41, 491-499. DOI: 10.1016/S0165-2370(97)00014-4

Chen, W., Shi, S., Zhang, J., Chen, M., and Zhou, X. (2016). "Co-pyrolysis of waste newspaper with high-density polyethylene: Synergistic effect and oil characterization," Energy Convers. Manage. 112, 41-48. DOI:

10.1016/j.enconman.2016.01.005

Chutia, R. S., Kataki, R., and Bhaskar, T. (2014). "Characterization of liquid and solid product from pyrolysis of Pongamia glabra deoiled cake," Bioresour. Technol. 165, 336-342. DOI: 10.1016/j.biortech.2014.03.118

Demiral, İ., and Şensöz, S. (2006). "Fixed-bed pyrolysis of hazelnut (Corylus avellana L.) bagasse: Influence of pyrolysis parameters on product yields," Energ. Source. Part A. 28(12), 1149-1158. DOI: 10.1080/009083190966126

Feng, J., Jiang, J., Yang, Z., Su, Q., Wang, K., and Xu, J. (2016). “Characterization of depolymerized lignin and renewable phenolic compounds from liquefied waste biomass," RSC Adv. 6(98), 95698-95707. DOI: 10.1039/c6ra16916c

Friedl, A., Padouvas, E., Rotter, H., and Varmuza, K. (2005). "Prediction of heating values of biomass fuel from elemental composition," Anal. Chim. Acta 544(1-2), 191198. DOI: 10.1016/j.aca.2005.01.041

Garcia-Perez, M., Chaala, A., Pakdel, H., Kretschmer, D., and Roy, C. (2007). "Characterization of bio-oils in chemical families," Biomass Bioenerg. 31(4), 222 242. DOI: 10.1016/j.biombioe.2006.02.006

Goutam, K. G., Pavan, K. G., and Monoj, K. M. (2019). "Experimental process parameters optimization and in-depth product characterizations for teak sawdust pyrolysis" Waste Management 15(87), 499-511. DOI: 10.1016/j.wasman.2019.02.035

Jahirul, M. I., Rasul, M. G., Chowdhury, A. A., and Ashwath, N. (2012). "Biofuels production through biomass pyrolysis - A technological review," Energies 5, 49525001. DOI: $10.3390 /$ en5124952 
Mamaeva, A., Tahmasebi, A., Tian, L., and Yu, J. (2016). "Microwave-assisted catalytic pyrolysis of lignocellulosic biomass for production of phenolic-rich bio-oil," Bioresour. Technol. 211, 382-389. DOI: 10.1016/j.biortech.2016.03.120

Nayan, N. K., Kumar, S., and Singh, R. K. (2013). "Production of the liquid fuel by thermal pyrolysis of neem seed," Fuel 103, 437-443. DOI: 10.1016/j.fuel.2012.08.058

Isah, Y. M., Yousif, A. A., Feroz, K. K., Suzana, Y., Ibraheem, A., and Soh., A. C. (2015). "Pyrolysis of napier grass in a fixed bed reactor: Effect of operating conditions on product yields and characteristics," BioResources 10(4), 6457-6478. https://www.researchgate.net/publication/280930292

Park, J., Lee, Y., Ryu, C., and Park, Y.-K. (2014). "Slow pyrolysis of rice straw: Analysis of products properties, carbon and energy yields," Bioresour. Technol. 155, 63-70. DOI: 10.1016/j.biortech.2013.12.084

Riva, L., Nielsen, H. K., Skreiberg, Ø., Wang, L., Bartocci, P., Barbanera, M., Bidini, G., and Fantozzi, F. (2019). "Analysis of optimal temperature pressure and binder quantity for the production of biocarbon pellet to be used as a substitute for coke," Applied Energy 256, 113933. DOI: 10.1016/j.apenergy.2019.113933

Raj, K. G., and Joy, P. A. (2015). "Coconut shell based activated carbon-iron oxide magnetic nanocomposite for fast and efficient removal of oil spills," J. Environ. Chem. Eng. 3(3), 2068-2075. DOI: 10.1016/j.jece.2015.04.028

Rout, T., Pradhan, D., Singh, R. K., and Kumari, N. (2016). "Exhaustive study of products obtained from coconut shell pyrolysis," J. Environ. Chem. Eng. 4(3), 36963705. DOI: 10.1016/j.jece.2016.02.024

Saikia, R., Chutia, R. S., Kataki, R., and Pant, K. K. (2015). "Perennial grass (Arundo donax L.) as a feedstock for thermo-chemical conversion to energy and materials," Bioresource Technol. 188, 265-272. DOI: 10.1016/j.biortech.2015.01.089

Salema, A. A., Afzal, M. T., and Bennamoun, L. (2017). "Pyrolysis of corn stalk biomass briquettes in a scaled-up microwave technology," Bioresour. Technol. 233, 353-362. DOI : 10.1016/j.biortech.2017.02.113

Uzun, B. B., Apaydin-Varol, E., Ateş, F., Özbay, N., and Pütün, A. E. (2010). "Synthetic fuel production from tea waste: Characterisation of bio-oil and bio-char," Fuel 89(1), 176-184. DOI: 10.1016/j.fuel.2009.08.040

Varma, A. K., Thakur, L. S., Shankar, R., and Mondal, P. (2019). "Pyrolysis of wood sawdust: Effects of process parameters on products yield and characterization of products," Waste Manage. 89, 224-235. DOI: 10.1016/j.wasman.2019.04.016

Venderbosch, R. H., and Prins, W. (2010). "Fast pyrolysis technology development," Biofuel. Bioprod. Bior. 4(2), 178-208. DOI: 10.1002/bbb.205

Wang, Z., Cao, J., and Wang, J. (2009). "Pyrolytic characteristics of pine wood in a slowly heating and gas sweeping fixed-bed reactor," J. Anal. Appl. Pyrol. 84(2), 179184. DOI: 10.1016/j.jaap.2009.02.001

Yakkala, K., Yu, M.-R., Roh, H., Yang, J.-K., and Chang, Y.-Y. (2013). "Buffalo weed (Ambrosia trifida L. var. trifida) biochar for cadmium (II) and lead (II) adsorption in single and mixed system," Desalin. Water Treat. 51(40-42), 7732-7745. DOI:

10.1080/19443994.2013.792546

Yin, C. (2012). "Microwave-assisted pyrolysis of biomass for liquid biofuels production," Bioresource Technol. 120, 273-284. DOI:

10.1016/j.biortech.2012.06.016 
Zhang, Q., Chang, J., Wang, T., and Xu, Y. (2007). "Review of biomass pyrolysis oil properties and upgrading research," Energy Convers. Manage. 48(1), 87-92. DOI: 10.1016/j.enconman.2006.05.010

Zhang, Y., Chen, P., Liu, S., Peng, P., Min, M., Cheng, Y., Anderson, E., Zhou, N., Fan, L., Liu, C., et al. (2017). "Effects of feedstock characteristics on microwave-assisted pyrolysis - A review," Bioresource. Technol. 230, 143-151. DOI: 10.1016/j.biortech.2017.01.046

Article submitted: November 24, 2019; Peer review completed: March 13, 2020; Revised version received and accepted: March 29, 2020; Published: April 3, 2020.

DOI: 10.15376/biores.15.2.3737-3755 